artigo $]$

\title{
Entre o humano e o divino: as vestes da Igreja Católica
}

\author{
Between human and divine: \\ the costumes of the Catholic Church
}

\section{[ FAUSTO VIANA ]}

Fausto Viana é figurinista, cenógrafo e pesquisador. Professor livre-docente da ECA-USP. Coordenou o projeto de catalogação do acervo de figurinos do Theatro Municipal de São Paulo. Participa do projeto de pesquisa As tramas do café com leite. Colabora com o blog www.vestindoacena.com.

E-mail: faustoviana@uol.com.br

[resumo] A base ritual da Igreja Católica é muito bem estabelecida. A mudança dos tempos não causou grandes interferências nos trajes da Igreja, que já atingiu 2000 anos de idade. Os formatos das vestimentas católicas de hoje têm 1400 anos. Este artigo investiga origens, simbologias e conseqüências do uso ritualistico dos paramentos religiosos.

\section{palavras-chave}

paramentos; trajes; catolicismo; indumentária; moda.

[abstract] The ritualistic basis of the Catholic Church has been very well established. The change of times did not affect the costumes of the church, which is now 2000 years old. The shapes of today's Catholic costumes were established 1400 years ago. This article investigates origins, symbolisms and consequences of the ritualistic use of canonicals.

[key words] canonicals; garments; Catholicism; attire; fashion. 


\section{Intróito}

Tudo começou por ocasião da morte de João Paulo II, em 8 de abril de 2005. Nas aulas de indumentária teatral na Universidade de São Paulo, desenvolvia-se o conceito de ritual e de vestimenta própria para a ocasião - afinal, o teatro é basicamente uma evolução do ritual dionisiaco. Assim, dentro das tendências contemporâneas da indumentária teatral e como parte de uma escola que deseja formar artistas pesquisadores em artes cênicas, os alunos são estimulados a investigar as diferentes manifestações ritualísticas envolvidas nas diversas religiões: umbanda, candomblé, judaísmo, hinduísmo (do qual os hare krishna são uma variante), evangelismo (referindo-me aos movimentos evangélicos) e muitas outras, entre elas, o catolicismo. Este artigo propõe uma investigação sobre os trajes da Igreja Católica Apostólica Romana e sua inserção em alguns rituais da mesma Igreja.

Com a morte de João Paulo II, nova disputa se iniciava - ou se completava - com a eleição do cardeal alemão Joseph Ratzinger. Um sacerdote conhecido como "linha dura" chegava ao cargo mais disputado pelos sedentos de poder da milenar Igreja Católica Apostólica Romana. Inicialmente, o novo papa definiu suas metas de atuação: combater o secularismo, conduzir a Igreja em novas reformas administrativas e exercer as atividades designadas ao "Santo Padre", que são "santificar, governar e ensinar, funções que, com o seu serviço ordinário supremo, pleno, imediato e universal, pode sempre exercer livremente buscando a salvação de todos". 1

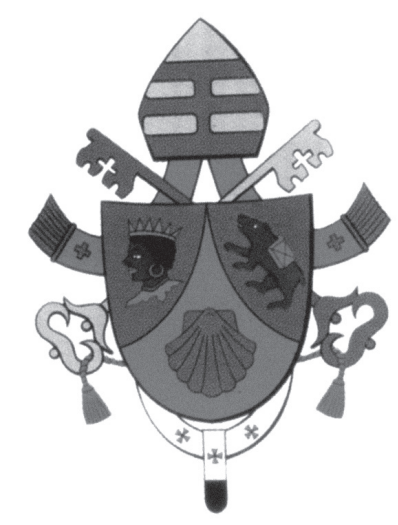

Figura 1- 0 brasão de Bento XVI

Impressa em seu brasão papal está uma capa, símbolo da "religião, que indica um ideal inspirado na espiritualidade monástica e, mais tipicamente, naquela beneditina"2. As metas papais vão se confrontar com inúmeras dificuldades católicas contemporâneas, como a perda de fiéis e os escândalos sexuais. A arquidiocese de Boston, nos Estados Unidos, estava enfrentando acusações de pedofilia, com cerca de "450 processos de abuso sexual, com ameaças de pedidos de indenizações cujo total superaria os US\$ 100 milhões.(...) Milhares de arquivos tornados públicos mostram que a Arquidiocese de Boston ocultou casos de padres acusados de abusos, incluindo clérigos que cheiraram cocaína e tiveram relações sexuais com meninas que queriam ser freiras"3. Os escândalos também envolviam o casamento dos padres e as discussões em torno de temas polêmicos: aborto, homossexualismo, divórcio e 0 uso de camisinhas como contraceptivos.

A escolha do próprio nome do novo papa (Bento XVI) remete a Bento XV, que foi o "papa da paz", mas também responsável por uma grande reforma administrativa da Igreja. Ao abolir a tiara de seu escudo, o papa mostra que reconhece que a separação entre Estado e lgreja definitivamente ocorreu, o que é moderno e lúcido.

A Igreja, no entanto, não deixa de lado sua magia ritualística. As encenações oficiais permitidas acontecem em diversos espaços cênicos: nas procissões de rua, nos cemitérios, nos hospitais, nos altares e dentro das igrejas, obviamente. Não raro acusa-se a lgreja de promover outras encenações não permitidas, em lugares menos oficiosos. A luz (difusa, aparentemente insuficiente) e a música, estabelecida de acordo com o que se está desenvolvendo, complementam 0 ritual. As personagens são os sacerdotes, os ministros e os que estão a serviço da liturgia. Os próprios fiéis se confundem nos papéis de público e personagens, agindo ora passiva, ora ativamente.

\section{Kyrie Eléison}

Ter uma formação católica tradicional não é coisa que se despreze. Nem que se possa ou consiga desprezar, pois a construção do pensamento católico - atenção: a referência não é ao pensamento cristão, que pode ser vertiginosamente distante - é muito bem-feita desde o berço. Ou da pia batismal. 
Há uma intrínseca relação das vestes com todos os momentos de transição na Igreja Católica. Não que a simbologia não seja perfeitamente adequada aos ritos propostos, nem que a verdade cristã não esteja por trás do cerimonial. Claro que a principal questão vem de quem exerce a autoridade eclesiástica e dela se aproveita. Na pia batismal, início da "carreira" de qualquer cristão, espera-se uma veste branca, alva, condizente com a pureza de quem vai receber o batismo. Esta veste, conforme já entendiam os primeiros cristãos, é usada para significar "a renovação" de todo o ser, essa transformação de vida interior que o batismo dá, revestindo o neófito com uma longa túnica imaculada. Hoje ainda, se bem que essa túnica seja mais freqüentemente substituida por um simples véu branco, a lgreja manda que se revista o neocristão, ao sair da pia batismal, com uma veste especial, transmitindo-Ihe, pelos lábios do sacerdote, a mensagem: "Recebe esta veste branca, que deverás apresentar sem mancha diante do tribunal de Nosso Senhor Jesus Cristo, a fim de obteres a vida eterna" (LESAGE,1959, p. 80).

A certeza de um julgamento final é reforçada novamente em outros sacramentos: a primeira comunhão, a crisma, o casamento, a extrema-unção. Todos, de uma forma ou de outra, pedem trajes específicos, de acordo com o momento.

\section{Longa jornada noite adentro}

$\mathrm{Na}$ bem organizada estrutura da Igreja Católica - a única empresa de alcance mundial que já dura 2 mil anos o estudo da indumentária religiosa está dentro da liturgia que, de forma reduzida, quer dizer "culto divino". Os livros de liturgia trazem as regras para a execução do ritus.

Não é fácil, no entanto, penetrar neste universo. A.B., um controverso aspirante a sacerdote que pediu que sua identidade não fosse revelada, disse: "São poucos os padres que entendem de liturgia, apesar de muitos falarem que sim. No seminário, a liturgia é parte integrante dos estudos, mas não há nenhum aprofundamento em relação à indumentária. Trabalham-se os procedimentos da cerimônia, o uso do turíbulo e do aparato religioso, mas este é um conhecimento que só vai se efetivar na prática, muito depois, já no exercício da atividade".

Poucos padres, no entanto, vão se interessar pela indumentária e suas origens. Estes, justamente por terem informações importantes, "não gostam de dividir, porque ter este conhecimento dá prestígio, dá status. 0 padre que sabe dos paramentos pode até ensinar algumas coisas, mas não tudo", afirma A.B.

0 mergulho na literatura católica contemporânea deixa a lacuna ainda mais evidente. Os manuais de liturgia são precários no que se referem aos têxteis. Explicações superficiais parecem destinadas a informar coroinhas aspirantes de como deve ser sua roupa. Não há nenhum procedimento no que tange aos cuidados que a indumentária ritualística exige - não só pela preservação têxtil, mas pela sacrossanta função que passa a exercer, assim que toca o corpo do sacerdote, como registra a epígrafe deste texto. Essa transmutação da roupa cotidiana em ritualística, mágica, para operar entre o humano e o divino, acontece em diversas religiões. Lembra-se da "roupa de ir à missa"? Normalmente, além de tudo, era a melhor que o fiel poderia alcançar em termos financeiros.

Espalhando luz na escuridão, frei José Ariovaldo da Silva, do Instituto Teológico Franciscano de Petrópolis, indicou a saída para tantos questionamentos. A partir do acervo da biblioteca do próprio Instituto, frei José elabora mentalmente roteiros que possam levar a um entendimento do que a indumentária religiosa católica significa e de como traçar um perfil desta trajetória no Brasil. Como parte de um projeto de pesquisa intitulado As tramas do café com leite, a visita a Petrópolis renderia ainda muitas descobertas com relação a um item investigado pelo projeto: a veste religiosa usada no Brasil no período da República Velha em São Paulo e Minas Gerais.

Com sabedoria, o frei faz uma análise do que significou a vinda da Igreja para a América Latina, não deixando de perceber suas nuances mais destrutivas na interação da religião com a atividade estatal.

\section{Lux in tenebris - os trajes dos nossos primeiros sacerdotes}

Não se pode acreditar, em princípio, que os padres da Companhia de Jesus (que aqui chegaram em 1549) desejavam destruir a nação indígena brasileira. A motivação de padre Manuel da Nóbrega ou de José de Anchieta era claramente missionária, de acordo com os relatos feitos por eles mesmos. Parece não haver nenhuma ambição pessoal de enriquecimento ou manipulação de poder. Havia 
o desejo extremo de alcançar e converter o máximo de almas possível. Não se pode, naturalmente, estender esta bondade de julgamento a todos.

Este pequeno retorno histórico serve apenas para indicar alguns curiosos fatos. Pero Vaz de Caminha, por exemplo, na Carta do Descobrimento, descreveu que os nossos nativos andavam nus. Teve também - obrigação de relatar os fatos - tempo para perceber que os índios dormiam

sem procurarem maneiras de encobrir suas vergonhas, as quais não eram fanadas; e as cabeleiras delas estavam bem rapadas e feitas e que uma das índias era tão bem feita e tão redonda, e sua vergonha tão graciosa que a muitas mulheres de nossa terra, vendo-Ihe tais feições envergonhara, por não terem as suas como ela. ${ }^{4}$

Não foi como Diogo Dias ${ }^{5}$ que agiram Anchieta e Nóbrega, que pareciam atender ao pedido de Caminha para que a Santa Fé Católica cuidasse da salvação dos nativos.

Anchieta, cujo manto (de autenticidade contestada por alguns) ainda pode ser visto no Pátio do Colégio, região central de São Paulo, viria a ser um dos grandes divulgadores dos trajes religiosos no Brasil. Nas encenações de seus autos, livremente inspirados nas encenações portuguesas dos autos de Gil Vicente, a indumentária teria uma função significativa.

Representações da vida de santos e instrumento de catequização dos índios, os autos colocaram em cena os indígenas vestidos. As personagens de santos e entidades celestiais vestiam-se com roupas européias, e aquelas que deveriam ser atacadas, pois interferiam na "educação" dos índios, eram vestidas como as entidades que faziam parte do culto dos nativos. Os trajes locais - as penas, os trançados - são relegadas à categoria de roupas demoníacas. Após a chegada dos jesuítas, o vestir - e o despir - no país jamais seriam os mesmos.

\section{Enquanto isso, no Vaticano....}

Anchieta e Nóbrega traziam os trajes dos missionários da Companhia de Jesus, que não fugiam muito aos moldes de outras irmandades da Idade Média. As diversas representações pictóricas de Anchieta e Nóbrega, ao longo dos tempos, mostram a tradicional batina preta, representante da pobreza, da devoção ao próximo e a Deus, acima de todas as coisas.

Em Roma, no entanto, os acontecimentos seguiam em outra direção. De acordo com Eamon Duffy, o papa Alexandre VI (que exerceu o Papado entre 1492 e 1503) encontrava-se altamente resistente às reformas solicitadas pelo mundo cristão com a maior urgência. Pudera: Alexandre VI, um descendente dos Bórgia, estava criando problemas ao manter amantes, nomear parentes para cargos políticos, tentar concentrar o poder nas mãos de sua família. Além de romper outras tradições religiosas, ao casar a filha Lucrécia Bórgia pela terceira vez. 0 primeiro casamento fora anulado; o segundo terminou com a morte do marido, provavelmente assassinado pelo outro filho do papa, César Bórgia.

Um olhar mais atento aos trajes de Alexandre VI (Figura 2) vai fazer com que o leitor se pergunte o porquê da semelhança entre as figuras 3 e 4, já que séculos separam as três imagens.

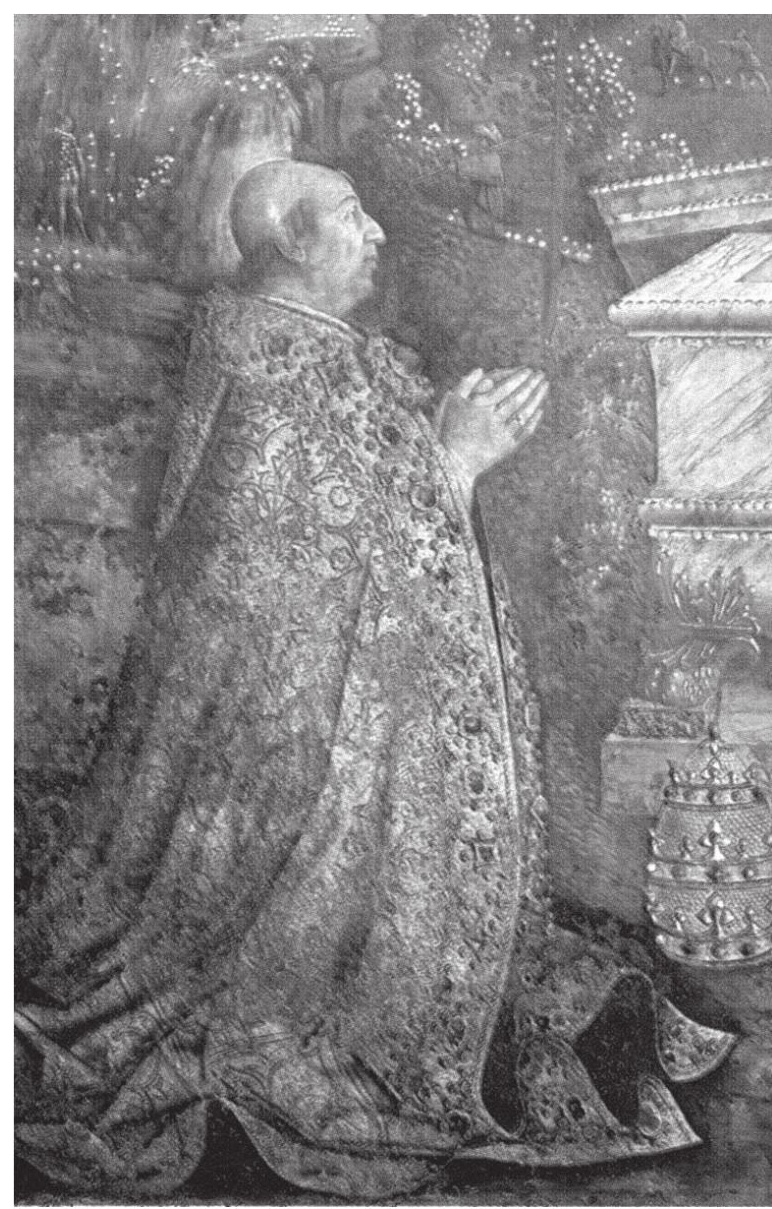




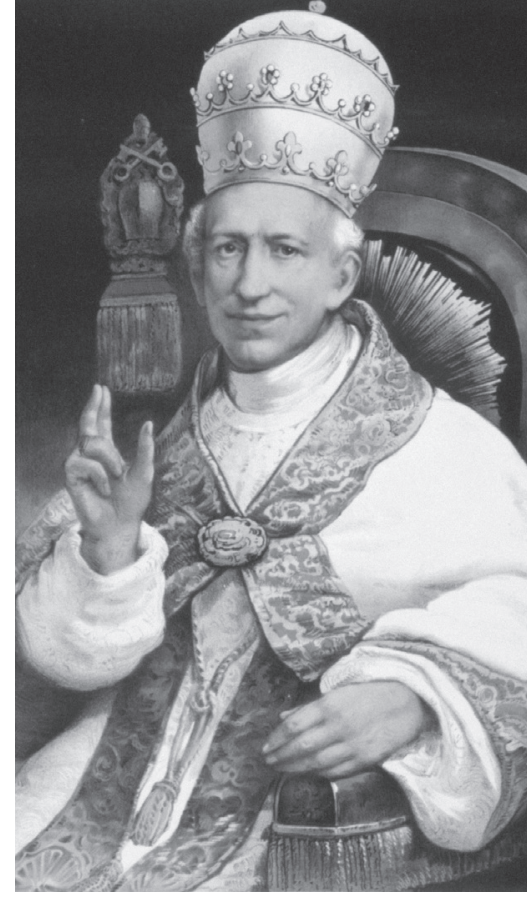

Figura 3 - Leão XIII (1878-1903)

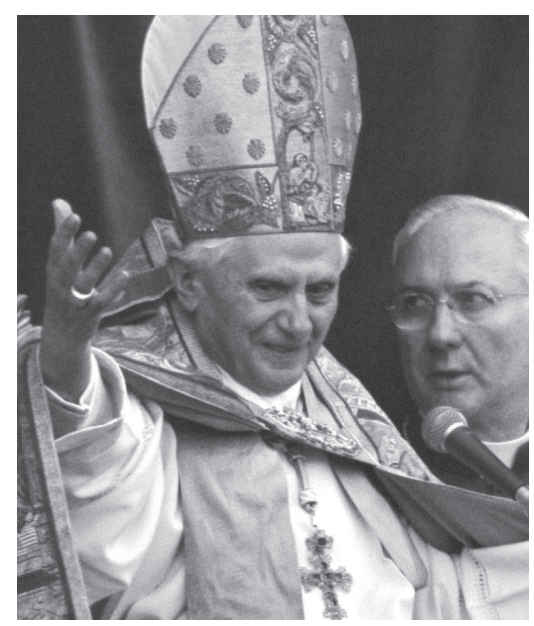

Figura 4- Bento XVI (2005- )

Os três portam quase os mesmos trajes. Na cabeça, com exceção de Bento $X V I$, a tiara papal (a de Alexandre VI está no chão). Segundo Rower, a tiara, é uma

coroa papal extra-litúrgica. Tem sua origem no camelaucum papal que, desde $0 X$ século, foi crescendo em tamanho e tomando a forma cônica, oval ou quase cilindrica. Como ornato, recebeu três coroas de metal enfiadas, a primeira no XII século, a segunda no tempo de Bonifácio VIII (falecido em 1303) e a terceira pouco depois. Os liturgistas interpretam as três coroas como símbolo do poder do papa, de Bispo e de Rei, ou da tríplice Igreja militante, padecente e triunfante. (...) 0 uso da tiara limita-se à cerimônia da coroação e aos préstitos solenes, antes e depois das funções pontificias na Basilica de São Pedro. (1938, p.120)

Joseph Ratzinger abriu mão deste símbolo até em seu brasão, optando pela mitra, que pode ser de três tipos: a auriphrygiata (dourada, que ele veste na foto); a mitra pretiosa, ou mitra preciosa, que é ricamente adornada e com pedraria e a mitra simplex, ou mitra simples, que é branca e lisa. A capa é chamada capa de asperges ou pluvial. Trata-se de um

manto grande sem pregas e acolchetado adiante, com uma peça em forma de escudo (clipeus) nas costas na qual se acha, freqüentemente, um monograma mais ou menos ricamente bordado, e com tiras verticais simples ou bordadas, nos dois lados da frente. (...) Hoje é usada também na bênção sacramental, nas exéquias e na aspersão dos fiéis, antes da Missa de Domingo, donde the vem o nome capa de asperges. (...) Como era usada também nas procissões e por isso tinha capuz como resguardo contra a chuva (pluvia) chamavam-na também pluviale. Como veste litúrgica é conhecida desde o IX século, vindo a substituir a casula, que então passou para uso exclusivo na Missa. (...) A cor da capa de asperges obedece às leis gerais sobre a cor dos paramentos, sua matéria geralmente é seda sem ser estritamente prescrita. (ROWER, 1938, p. 30)

Trajam também, por baixo, uma alva, que é uma túnica branca talar, ou seja, que desce até os calcanhares.

\section{Origens do traje eclesiástico}

Boucher cita que é a partir do século VI que em Roma "um certo número de trajes seculares de uso corrente passaram a ter um sentido religioso, e até certo ponto, caráter simbólico, assim criando um traje que ficou codificado em seu uso e fixado em sua forma" (1987, p.166).

Prosseguindo na identificação, Boucher afirma que a túnica (de origem síria e egípcia, curta, com mangas largas e corpo mais justo), a alba (variação da túnica clássica, longa e de linho), a casula (traje comum a ambos os sexos, um pedaço de tecido em formato arredondado com um buraco central para a cabeça, mais curta na frente e com aberturas dos dois lados para a passagem 
das mãos) e a capa pluvial eram parte desses trajes. A Igreja teria adotado ainda a estola (mesmo uso atual, adaptação do traje grego loros), o manípulo (uma espécie de lenço que se transformou até atingir o formato atual) e o pálio, derivado do pallium, uma capa romana drapeada.

Há indícios de que no Quarto Concílio de Cartago, em 589, os diáconos e o clero mais baixo foram proibidos de usar a túnica alba e a túnica talaris fora das igrejas e das ocasiões cerimoniais, o que enfatiza seu caráter litúrgico (BOUCHER, 1987).

Já na Idade Média, "os próprios papas viviam profundamente enredados nas guerras intestinas da nobreza romana e, como vimos, com muita freqüência a eleição para a cadeira de Pedro era uma mercadoria à venda ou a ser barganhada" (DUFFY,1998, p. 87). Johnson, por sua vez, reforça esta teoria ao afirmar que no século XIII, "as abadias beneditinas praticamente haviam deixado de ser instituições espirituais. Tornaram-se sinecuras colegiadas, reservadas em grande parte aos membros das classes mais altas" (2001, p. 284).

Pois foram estes nobres, que consumiam todos os bens dos fiéis em bebidas e gastos exagerados, que introduziram o luxo dos tecidos nas vestimentas religiosas medievais. Se o sistema levava, por exemplo, viúvas a serem enviadas a um convento, por que elas haveriam de abrir mão do luxo em que viviam? Os conventos e o ritual cristão vão sendo impregnados pelos valores mundanos.

Só no Concílio de Trento, em 1545, é que o inquisidor Michele Ghislieri, que se tornaria o papa Pio V, conseguiu oficializar a imposição de trajes clericais estritos. Mas isto foi feito sob os olhares do bispo de Trento, o cardeal Ippolito d'Este, "belo, bem-nascido e de boas relações e que sempre envergava o traje de veludo vermelho de um príncipe secular - somente seu barrete vermelho traía o fato de ser um clérigo" (JOHNSON, 2001, p. 360).

A Igreja voltaria a analisar a questão dos trajes novamente apenas no Concílio Vaticano I (1870) e, já na década de 1960, no Concílio Vaticano II, quando pequenas mudanças foram autorizadas. Um exemplo é o uso das luvas episcopais, que não foram proibidas, mas deixaram de ser mencionadas. Outro é a flexibilização quanto aos padrões visuais impostos nos desenhos a serem aplicados nos trajes, para os quais a "Igreja admite o gênero e o estilo artístico de cada região, e aceita as adaptações que correspondem à mentalidade e às tradições de cada povo... deve haver o cuidado de manter nobre simplicidade" (grifo do autor) (IGMR, 287)6.
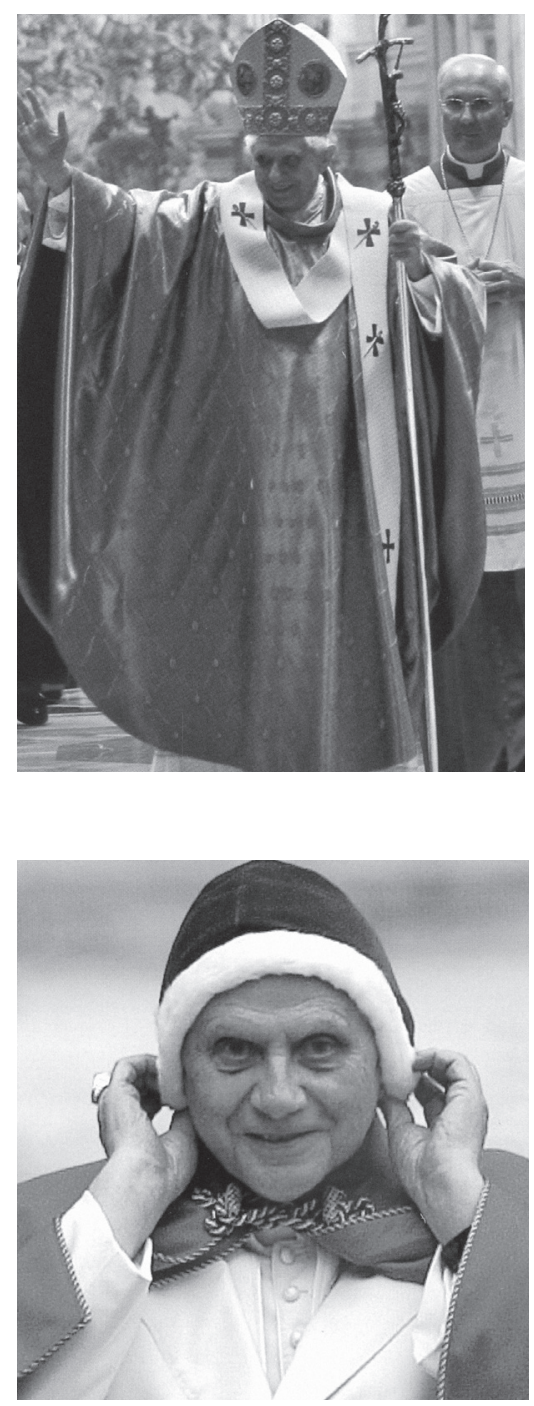

Figura 6 - Bento XVl e o camauro

Não é pela execução ou criação dos trajes que se pode condenar o atual papa, já que são confeccionados pela Gammarelli, uma empresa que presta serviços ao Vaticano desde 1792. Até mesmo o Pravda, jornal russo, noticiou:

Quando cardeal, Bento usava basicamente preto. Agora pode ser visto vestido em maravilhosos trajes roxos e vermelhos, com acabamento em peles e fivelas douradas. Neste feriado nas montanhas, o Pontífice foi visto usando um boné branco de baseball. O Papa Bento XVI não hesita em usar roupas de marcas conhecidas mundialmente que estão em seu guarda-roupa. Fez uma aparição 
pública uma vez usando óculos de sol espelhados Gucci.

Uma loja Gammarelli é das mais elegantes da Via dei Cestari, perto do Panteão. A rua é como a Via Montenapoleone para os sacerdotes do Vaticano. Vende luvas rosa com bordado dourado e tecidos luxuosos para bispos e cardeais. $^{7}$

0 papa causou ainda mais furor quando se anunciou que seus sapatos são Prada, na mesma época do lançamento do filme $O$ diabo veste Prada. Não bastasse isso, muita gente riu quando Bento XVI apareceu em público, no Natal de 2005, com um chapéu vermelho, que todos diziam ser uma brincadeira com o Papai Noel. Era um camauro (Figura 6), um gorro de origem medieval feito de veludo (no inverno) ou seda (no verão) e debruado de pêlo de arminho (o que causou a ira dos ecologistas). Ao resgatar este adereço, por exemplo, Bento XVI dá mostras de que se apóia no que a Igreja tem de mais tradicional, ou talvez, melhor dizendo, antigo.

A veste papal da Figura 5, no entanto, é muito mais instigante do que se pode supor. 0 homem que está ali fotografado não parece ser a representação da ponte espiritual entre os homens e 0 deus que adoram. Lembra mais uma encarnação material do desejo não da sublimação, mas da permanência e apego aos bens terrenos.

A mitra é um símbolo antiqüíssimo, um triângulo que representa a ligação entre o mundo espiritual e a matéria. Pode simbolizar também a triade Pai-FiIho-Espírito Santo. Há quem interprete o triângulo como a trajetória do homem na evolução espiritual: sai do mundo etéreo, chega, vive e volta ao lugar de origem puro e evoluído. No entanto, mesmo simbolicamente, a mitra se encontra hoje dividida em duas partes e em um formato arredondado, o que the confere uma polaridade feminina. A triade, o três, no entanto, é ímpar e masculino. No mínimo, tem-se uma estrutura conflitante, mas que tem representação na arquitetura das igrejas: é o caso das góticas, com seu formato de teto que, explica a lgreja, lembra o de mãos espalmadas em oração.

A aparente confusão se amplia quando atentamos para o corte da rou- pa. Como citado, o pluvial tem origem em um corte arredondado, com um furo ao meio. Não fosse a simbologia feminina evidente no formato, ainda há a "agravante" de termos um traje que encobre o corpo masculino por inteiro, com exceção da cabeça e, ocasionalmente, das mãos.

0 frei Plácido de Andrade Barroco, em sua dissertação escrita em 1791, também questiona o porquê da inclusão dos trajes femininos. Esta é a sua reflexão:

A estola era entre os Romanos um vestido próprio das mulheres, chamado muitas vezes túnica, que elas usavam debaixo do seu manto palla, ou pallium. Correspondia à túnica, que os homens traziam embaixo da toga. É dificultoso na verdade explicar como um vestido próprio das mulheres viesse, não dizemos a servir aos homens, mas a ser próprio dos Ministros Sagrados. Eis aqui em duas palavras como conjecturam os mais ilustres escritores. Calígula e outros Imperadores de tal sorte se deram ao luxo, que trajavam os mesmos vestidos das mulheres. Isto bastou para que a estola, correndo os tempos, fosse comum a ambos os sexos $\mathrm{e}_{\text {, conseqüentemente viesse a servir }}$ no altar. Em quanto (sic) a mudança extraordinária acrescentam que este vestido, sendo naturalmente simples, tinha todavia nas extremidades uma bordadura, ou barra preciosa. (BARROCO, 1791, p. 41)

A "Santa Mãe" se apresenta, portanto, desta forma: um corpo masculino, oculto sob formas e intenções ditas femininas, de proteção, orientação e condução. Em princípio, parece contraditório - não fossem os verdadeiros desejos da Igreja Católica.

Ao menos do ponto de vista dos trajes, a Igreja busca uma sistemática de representação que garante ao fiel apenas o entendimento mínimo do que está acontecendo. As cores são estabelecidas, de maneira geral, para que o fiel acompanhe

o sentimento progressivo da vida cristã em sua caminhada ao longo do ano litúrgico (por exemplo, o lilás da purificação em preparação às celebrações do Natal e da Páscoa do Senhor, o branco dos períodos da celebração jubilosa dos mesmos mistérios, o verde no tempo comum 
vivo na confiante espera das últimas realidades). (SARTORE, 1992, p. 19)

0 colorido variado dos paramentos, ainda segundo Sartore, tem como objetivo demonstrar exteriormente as características particulares dos mistérios celebrados a cada dia.

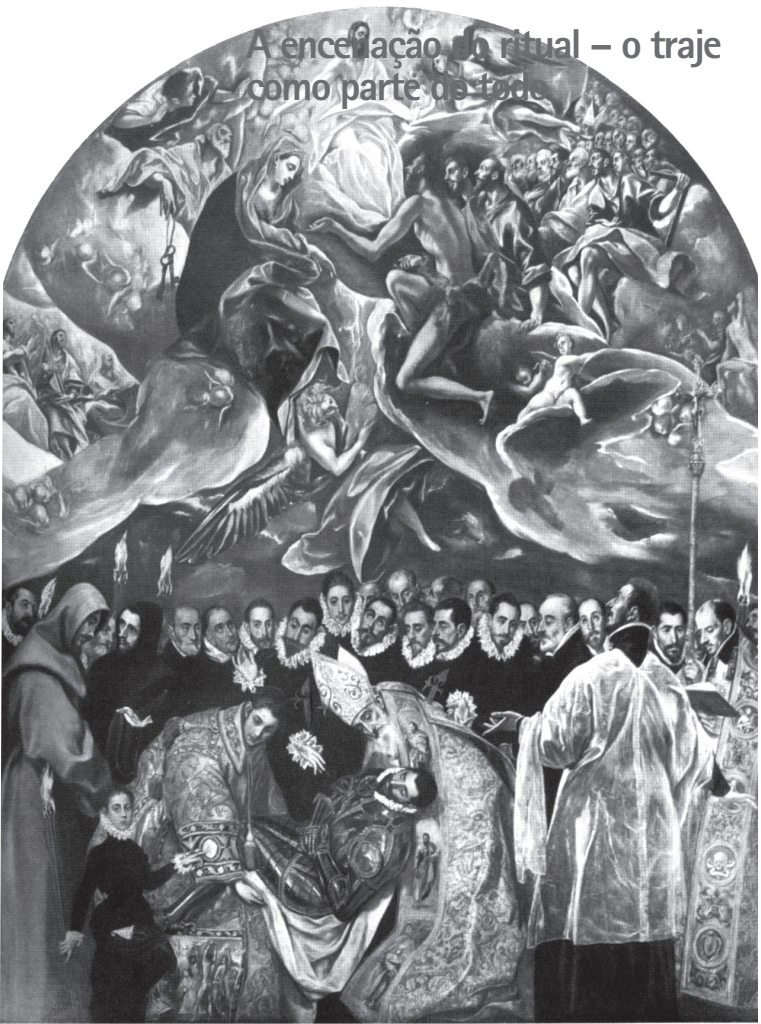

Figura 7- 0 Enterro do Conde de Orgaz, de 1586. Autor: El Greco

Temor a Deus, em princípio, quer dizer respeito a Deus. Mas cada vez mais vivemos uma situação de medo, no sentido mais atual da palavra. 0 sacerdote é um ser sobrenatural, místico, que consegue transpor limites impostos ao homem comum. Por sacerdote entende-se xamã, guia, rabino, pastor, médium, cavalo ou qualquer que seja a denominação recebida nas mais diversas religiões. É o ser que alcança além dos limites dos olhos materiais - anda pelos caminhos da pós-matéria, da pós-morte. Seu entendimento de vida e morte devem ajudar outros seres humanos a enfrentar os desafios da evolução.

El Greco (Figura 7) mostra uma curiosa profusão de trajes. Na parte inferior do quadro, que retrata o plano material, estão os ricos trajes da Igreja Católica espanhola, inclusive das irmandades, e os luxuosos trajes da corte espanhola que acompanham o funeral do Conde de Orgaz, ricamente vestido com uma armadura preta e dourada. Na parte de cima, representando graficamente o plano espiritual, o Conde é recebido por Jesus, Maria e São João Batista, que guarda enorme semelhança física com o próprio Conde.

A diferença é que o mundo espiritual traja-se com panos muito simples. São João usa peles de cabras e restos de panos. É neste universo que a alma vai entrar, alerta o pintor.

No universo terreno do quadro vivem os católicos. Inadvertidamente, seus trajes sacerdotais continuam sendo usados para firmar a posição dos homens que fazem a transição entre vida e morte, matéria e espírito, palpável e sensorial. No caso do papa, daquele que liga e desliga. Até bem pouco tempo, a missa rezada em latim era entendida por poucos. A função teatral dos trajes, da música e da encenação supria sensorialmente o que à razão não era permitido entender.

Poucas alterações ocorreram na roupa oficial da Igreja em um longo período. Improvável esperar uma mudança significativa em breve.

A.B., o futuro sacerdote que deseja se manter no anonimato, aponta que já faz algum tempo que não há a necessidade de se usar o traje em determinadas irmandades.

\begin{abstract}
Os seminários diocesanos, que não são religiosos como os beneditinos, por exemplo, não têm mais necessidade de usar o hábito, apenas uma espécie de túnica muito simples. Eles podem usar uma camisa clergyman, ou uma túnica de cor preta com clergyman", conta A.B. Os seminaristas, por exemplo, podem andar à paisana, com uma "correntinha básica" com uma cruz, ou um anel de Nossa Senhora, ou com pontinhos que marcam o terço.
\end{abstract}

Mas faz questão de lembrar que várias irmandades ainda portam seus trajes tradicionais. Tal como A.B., que anda às voltas com as suas opções sexuais, Bento XVI precisa tomar algumas decisões que sejam definitivas. Um bom início, no que se refere aos trajes, seria buscar inspiração no próprio livro sagra- 
do do catolicismo. Seria bom lembrar que seu orientador maior, Jesus, quando morreu, suas vestes foram disputadas pelos soldados que o crucificaram, efetivando antiga profecia: "Repartiram entre si minhas vestes e sobre meu manto lançaram a sorte" (SI 21,19). Há muito mais símbolos aqui do que pode suportar um breve artigo. Mateus certamente não aceitaria a produção de Gammarelli: "Olhai para os lírios do campo, como eles crescem; não trabalham nem fiam; E eu vos digo que nem mesmo Salomão, em toda a sua glória, se vestiu como qualquer deles" (Mt 26.28,29). Talvez fosse o caminho a ser seguido pela lg-

\section{NOTAS}

[1] Disponivel em: <http://www.cnbb.org.br/index.php?op=noticiactsubop=7795>. Acesso em: 22 fev 2008.

${ }^{[2]}$ Disponivel em: <http://www.cnbb.org.br/index.php?op=noticiactsubop=7795>. Acesso em: 22 fev 2008.

${ }^{[3]}$ Disponivel em: <http://www1.folha.uol.com.br/folha/mundo/ult94u101297.shtml>. Acesso em: 23 fev 2008.

${ }^{[4]}$ Disponivel em: < http://www.eduquenet.net/cartacaminha.htm>. Acesso em: 23 fev 2008.

${ }^{[5]}$ Diogo Dias era um dos membros da expedição em que estava Pero Vaz. Era muito divertido e fazia festa com os indios, tocando gaita e dançando com eles.

[6] Missale Romanum, do Institutio Generalis Missalis Roman. Ed. Typica Tertia, Typis Vaticanis, 2002.

[7] Disponivel em: <http://english.pravda.ru/world/europe/10-04-2007/89452-pope benedict-0>. Acesso em: 23 fev 2008.

\section{REFERÊNCIAS}

BARROCO, Frei Plácido de Andrade (1750-1813). Dissertação: sobre a origem das vestes sagradas na lei da graça. Lisboa: Regia Officina Typpografica, 1791.

BOUCHER, François. 20.000 years of fashion. Nova York: Harry N. Abrams, 1987.

DUFFY, Eamon. Santos e pecadores - história dos papas. São Paulo: Cosac \&t Naify, 1998.

JOHNSON, Paul. História do cristianismo. Rio de Janeiro: Imago Editora, 2001.

ROWER, Frei Basílio. Diccionário litúrgico. Petrópolis: Vozes, 1928.

SARTORE, Domenico; TRIACCA, Achille M. Dicionário de liturgia. São Paulo: Paulus, 1992.

\section{CRÉDITOS PARA FIGURAS:}

Figura 1: Site do Vaticano (www.vatican.va/phome_po.htm)

Figura 2: Afresco de Pinturicchio, nos aposentos dos Bórgia, no vaticano.

Fonte: DUFFY, Eamon. Santos e pecadores - história dos papas. São Paulo: Cosac \& Naify, 1998, p. 146.

Figura 3: Biblioteca do Congresso Norte-Americano, imagem de domínio público.

Figura 4: Foto de Gianni Giansati.

Fonte: ISRAELY, Jeff. Bento XVI - o alvorecer de um novo papado. São Paulo: Escrituras, 2007, p. 172.

Figura 5: Foto de Gianni Giansati

Fonte: ISRAELY, Jeff. Bento XVI - o alvorecer de um novo papado. São Paulo: Escrituras, 2007, p. 166.

Figura 6: Foto de Gianni Giansati

Fonte: ISRAELY, Jeff. Bento XVI - o alvorecer de um novo papado. São Paulo: Escrituras, 2007, p. 174.

Figura 7: 0 Enterro do Conde de Orgaz, de El Greco, domínio público.

Fonte: JANSON, H.W. História da Arte. São Paulo: Martins Fontes, 1992. 